S. Afr. J. Agric. Ext.,

Vol. 45, No. 2, 2017: 49 - 63

Kotey, Assefa \&

DOI: http://dx.doi.org/10.17159/2413-3221/2017/v45n2a433

Van den Berg.

(Copyright)

\title{
ENHANCING SMALLHOLDER FARMERS' AWARENESS OF GM MAIZE TECHNOLOGY, MANAGEMENT PRACTICES AND COMPLIANCE TO STEWARDSHIP REQUIREMENTS IN THE EASTERN CAPE PROVINCE OF SOUTH AFRICA: THE ROLE OF PUBLIC EXTENSION AND ADVISORY SERVICES
}

Kotey, D. A., ${ }^{11}$ Assefa, Y. ${ }^{12} \&$ Van den Berg, J. ${ }^{13}$

\section{ABSTRACT}

Genetically modified (GM) maize technology adoption is subject to compliance with stewardship requirements that promote the long-term effectiveness of the technology against target pests and weeds. Awareness of the value of these requirements can enhance farmer compliance and promote the adoption of improved management practices. A semi-structured questionnaire was used to interview 210 smallholder GM maize farmers in the Eastern Cape to assess farmers' awareness and compliance to GM maize technology stewardship requirements. Field surveys were also conducted to identify the practices adopted for the cultivation of GM maize. Results indicated that farmers lacked access to information about GM maize and had a low level of awareness of GM maize stewardship requirements. Additionally, while the use of Bt maize resulted in fewer farmers reporting pest incidence, notably that of the maize stem borer, Busseola fusca (Lepidoptera: Noctuidae) on their farms, for some reason, there was an increase in the proportion of farmers that sprayed and relied solely on insecticides for controlling pests on Bt maize. A high proportion of farmers (71.4\%) also relied solely on herbicide sprays for controlling weeds in their herbicide tolerant maize fields. Field surveys also indicated non-compliance to the requirement for the planting of refuge areas adjacent to Bt maize. Training of extension service personnel on stewardship requirements for GM maize is urgently needed to improve its management and prevent loss of the benefits provided by GM maize technology.

Keywords: Extension, GM maize, information dissemination, smallholder farmer, stem borers

\section{INTRODUCTION}

GM maize seeds have enhanced traits that are patent protected (Monsanto, 2012; Jacobson, 2013:30; Fischer, Van den Berg \& Mutengwa, 2015:1). Additionally, owing to the risk of resistance evolution by target insect pests to the $\mathrm{Bt}$ (Bacillus thuringiensis) maize trait and weeds to herbicides (Tabashnik, 1994:47; Green \& Owen, 2010:5827), the use of GM maize is subject to compliance with technology stewardship requirements as provided for in the Plant Improvement Act (Act 53 of 1976), the Plant Breeders Rights Act (Act 15 of 1976), the South African Patents Act (Act 57 of 1978) the South African Trade Marks Act (Act 194 of 1993), the Genetically Modified Organisms (GMO) Act (Act 15 of 1997) and the GMO Amendment Act (Act 26 of 2006) (Monsanto, 2012). Farmers or end users of GM seeds are therefore required to sign stewardship agreements with GM technology licence holders when

\footnotetext{
${ }^{11}$ Department of Zoology and Entomology, University of Fort Hare, Alice, 5700, South Africa. Council for Scientific and Industrial Research-Plant Genetic Resources Research Institute, Bunso, Ghana.

12 Department of Zoology and Entomology, University of Fort Hare, Alice, 5700, South Africa. Department of Crop Production, Faculty of Agriculture, University of Swaziland, Luyengo, M205, Swaziland.

${ }^{13}$ Unit for Environmental Sciences and Management, North-West University, Potchefstroom, 2520, South Africa.
} 
S. Afr. J. Agric. Ext.,

Vol. 45, No. 2, 2017: 49 - 63

DOI: http://dx.doi.org/10.17159/2413-3221/2017/v45n2a433

they purchase GM crop seed. In these agreements they accept the conditions and responsibilities regarding the use of GM maize seed and comply with GMO user guidelines which stipulates adherence to the requirements regarding the adoption of appropriate insect and weed resistance management strategies (Monsanto, 2012:2; Pannar, 2014:17).

Farmers who plant maize with $\mathrm{Bt}$ traits are also required to plant refuge areas of non- $\mathrm{Bt}$ maize adjacent to their $\mathrm{Bt}$ maize fields so as to delay resistance evolution in target pests (Van den Berg, Hillbeck \& Bøhn, 2013:155). Farmers can comply with this requirement by either planting $20 \%$ of their maize area with conventional maize which may be sprayed with any non-Bt (active ingredient) insecticide or by planting a 5\% area with conventional maize which is left unsprayed (Van den Berg et al., 2013:155). To delay selection for weed resistance, it is also recommended that farmers abide by herbicide product label rates and proactively implement diversified weed control strategies including the use of multiple herbicides with different modes of action and overlapping weed spectra, with or without tillage operations and/or other cultural practices (Monsanto, 2012).

Thus, in contrast to the cultivation of seeds of open pollinated varieties (OPV) of maize, the cultivation of GM maize seed requires the adoption of new and improved management practices that ensure that farmers obtain the full benefits of GM maize and at the same time comply with stewardship requirements (Jacobson \& Myhr, 2012:5) that safeguard GM maize technology. Information dissemination and demonstration of the effectiveness of new technologies can be implemented through extension services and can contribute to increased awareness and appropriate use of these new technologies and management approaches amongst farmers (Ozowa, 1997:12; Abadi Ghadim \& Pannell, 1999:153; Cameron, 2007:376). The need therefore exists to determine the level of farmers' access to information about GM maize and how this contributes to awareness and compliance to GM maize technology stewardship requirements as well as the practices adopted by farmers in its cultivation. Such information can be used to ascertain if alternative strategies are required for smallholder farmers or existing ones need to be better implemented. This study evaluated farmers' perceptions and the practices they adopted for the cultivation of GM maize and its implications to GM maize pest and weed resistance management on smallholder farms.

\section{MATERIALS AND METHODS}

\subsection{Description of the study area and GM-maize cultivation practices in smallholder farms}

The study was conducted in five District Municipalities of the Eastern Cape where dry land agriculture is practiced (Figure 1). Two different cropping systems can be found in the province, namely, home-gardens and outfields. Home-gardens are small fenced plots of land (0.1-0.5 ha) that form an integral component of rural homesteads. Outfields on the other hand are relatively larger (1-5 ha) plots of land that are often not fenced and located a distance away from the homestead. The dominant crop in both systems is maize. In view of this, maize has been prioritized as the flagship crop in the Cropping Programme being implemented in the province. Since 2012, the Eastern Cape Rural Development Agency (ECRDA), a subsidiary of Department of Rural Development and Agrarian Reform (DRDAR), has been implementing the Cropping Programme on behalf of DRDAR (ECRDA, 2013). Participation in the Cropping Programme is conditioned on the ability of farmers to contribute $18 \%$ of the total cost of production per hectare. Although the amount contributed by a farmer or community indicates the potential area to be cultivated, the final area 

farmers' or community's production costs per hectare.

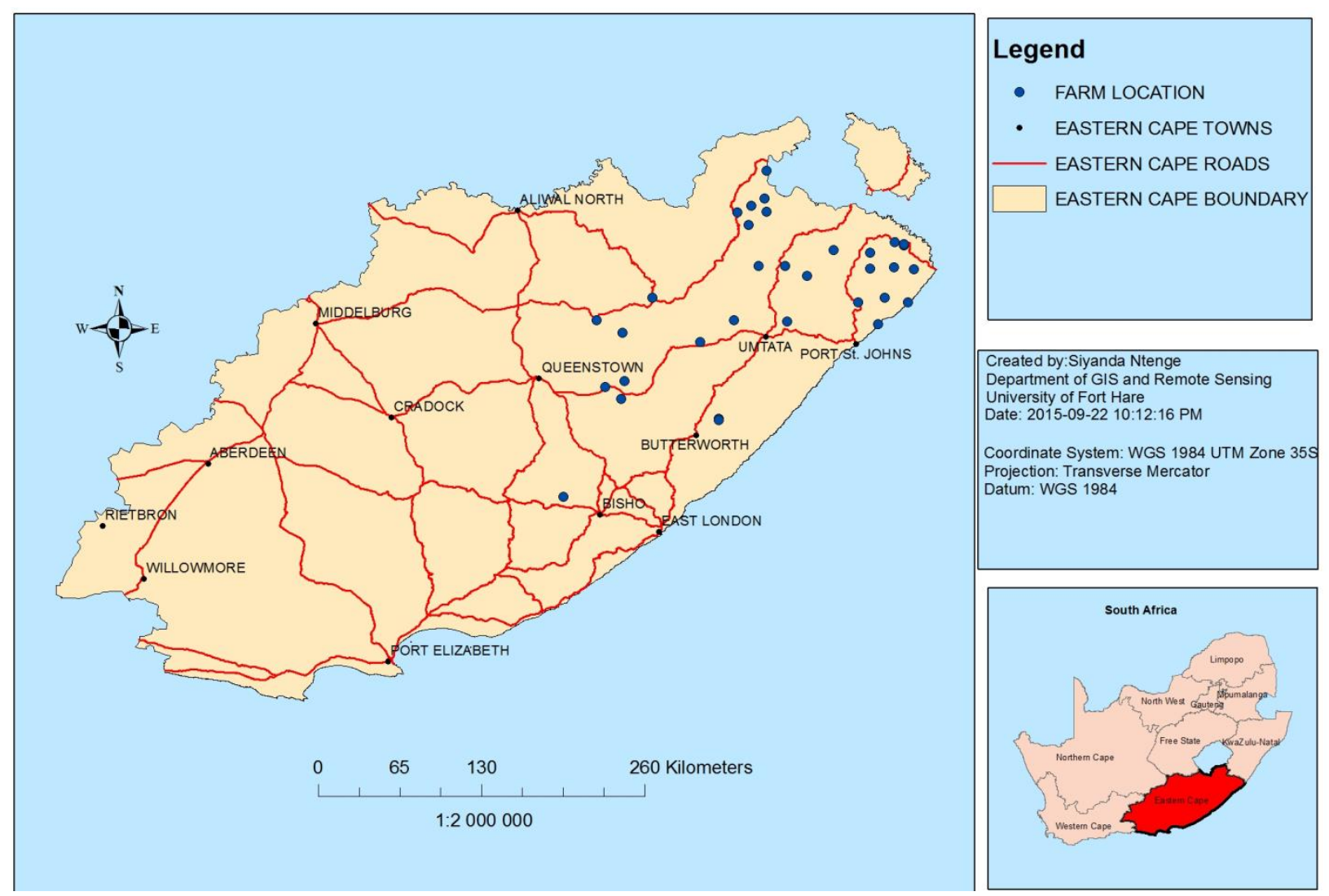

Figure 1: Map of the Eastern Cape Province indicating the localities (dark dots) where smallholder GM maize farmers were interviewed.

\subsection{Farmer survey}

When studying different aspects of agricultural technology adoption, a sample size of 60-120 respondents is recommended (CIMMYT, 1993). A total of 210 farmers were interviewed in this study using a semi-structured questionnaire with closed and open-ended questions. Areas where GM maize was cultivated as part of the Cropping Programme were identified with the assistance of chairpersons of farmer-committees in each District Municipality. Due to constraints of poor road accessibility, surveys were conducted only in rural areas within 20 $\mathrm{km}$ from the main access roads in each District Municipality (Figure 1). Farmers willing to participate in the survey in each area were individually interviewed. Each interview lasted about 30 minutes. The survey questionnaire was divided into four sections namely; personal profile of household head and household size, access to GM maize information and advisory services, awareness and compliance to GM maize technology stewardship requirements and GM maize pest and weed management practices. To obtain first-hand information about GM maize cultivation practices, GM maize fields in 14 localities (three fields per locality) were visited and inspected during the 2014/15 maize cropping season. Information regarding the GM maize variety (insecticidal Bt maize / herbicide tolerant maize (RR)) cultivated in the area, planting dates of maize, the distance between $\mathrm{Bt}$ and non-Bt fields, pest and weed management history and the presence or absence of refuge areas were recorded.

\subsection{Data analysis}


S. Afr. J. Agric. Ext.,

Vol. 45, No. 2, 2017: 49 - 63

DOI: http://dx.doi.org/10.17159/2413-3221/2017/v45n2a433
Kotey, Assefa \&

Van den Berg.

(Copyright)

Answers provided by farmers were coded and analysed using SPSS version 23 (IBM corporation, USA). Frequency counts and percentages were used to describe the personal and demographic profile of respondents and also summarise responses to questions regarding respondent's awareness of GM maize technology stewardship requirements. For all questions asked during interviews, percentages were calculated using the total number of respondents who answered a particular question. In cases where respondents did not answer a question, they were excluded from the calculation of percentage values for that question. Crosstabulations were used to determine the relationship between categorical variables. For example, the relationship between type of GM maize currently cultivated and farmers' perception of the benefit of cultivating GM maize, the relationship between farmers' participation in GM maize training and the number of times farmers applied insecticides onto their maize crop per season. Pearson chi-square test $\left(\chi^{2}\right)$ was used to determine if any observed relationships were significant.

\section{RESULTS}

\subsection{Personal profile of GM maize farmers}

Most (52.9\%) of the farmers interviewed were males between the ages of 51-70 (58.8\%) and had completed not more than seven years of formal education $(58.6 \%)$. Although the majority had been cultivating maize for more than 20 years $(71.2 \%)$ they had less than four years' experience $(73.2 \%)$ with GM maize which was mostly cultivated on communal land $(87.1 \%)$. Many (49\%) of the GM maize fields cultivated were within the size range of $0.5-1.0$ hectares (ha). The predominance of male farmers within the age bracket of 51-71 observed in this study is similar to the findings of previous studies on GM maize cultivation by smallholders in South Africa (Assefa \& Van den Berg, 2009:217; Gouse, 2012:168). Access to land has been reported to be a key determinant of the use of external inputs by farmers (Doss \& Morris, 2001:39; FAO, 2011). Although women constitute more than two-thirds of persons involved in smallholder agriculture in South Africa (Hart \& Aliber, 2012:2), their access to land in rural areas of the country is constrained by their gender and social position in the community (Commission for Gender Equality, 2009). Swanson \& Rajalahti (2010:85) however noted that male farmers are comparatively more favoured by extension services.

\subsection{Introduction of smallholder farmers to GM maize technology and access to information on GM maize}

Very few farmers $(4.8 \%)$ ascribed their decision to cultivate GM maize to the actual improved traits for which it was developed (resistance to insect pests and tolerance to herbicides) (Figure 2). The majority of farmers (70.48\%) cited encouragement by extension personnel as the principal reason that led to them to cultivate GM maize. Few farmers (34.9\%) reported participating in any training programme on GM maize technology prior to being introduced to the technology. Most of the training programmes attended by farmers were organised by DRDAR $(85.9 \%)$ and discussed single topics such as mechanisation of GM maize fields $(38.6 \%)$ or multiple topics such as mechanisation, pest management and fertiliser application $(21.1 \%)$ (Table 1). A few respondents $(15.8 \%)$ could not recollect the subjects discussed at the training workshops they attended.

The development of skills in the management of an agricultural technology innovation can be facilitated by trial prior to adoption (Abadi Ghadim \& Pannell, 1999:153). Adesina, 
Langyintuo, Bugo, Makinde, Bigirwa \& Wakiumu, (2011:286) reported that experimentation and use of incremental quantities of inputs such as seeds provide farmers the opportunity to choose technologies based on their own assessments of abiotic factors such as rainfall. Through this process, farmers may also be afforded the opportunity to learn to utilise specific technologies under evolving conditions, for example pest and disease infestation or government policies (Stone, 2011:393). This process has been referred to as 'agricultural skilling' (Stone, 2011:393).

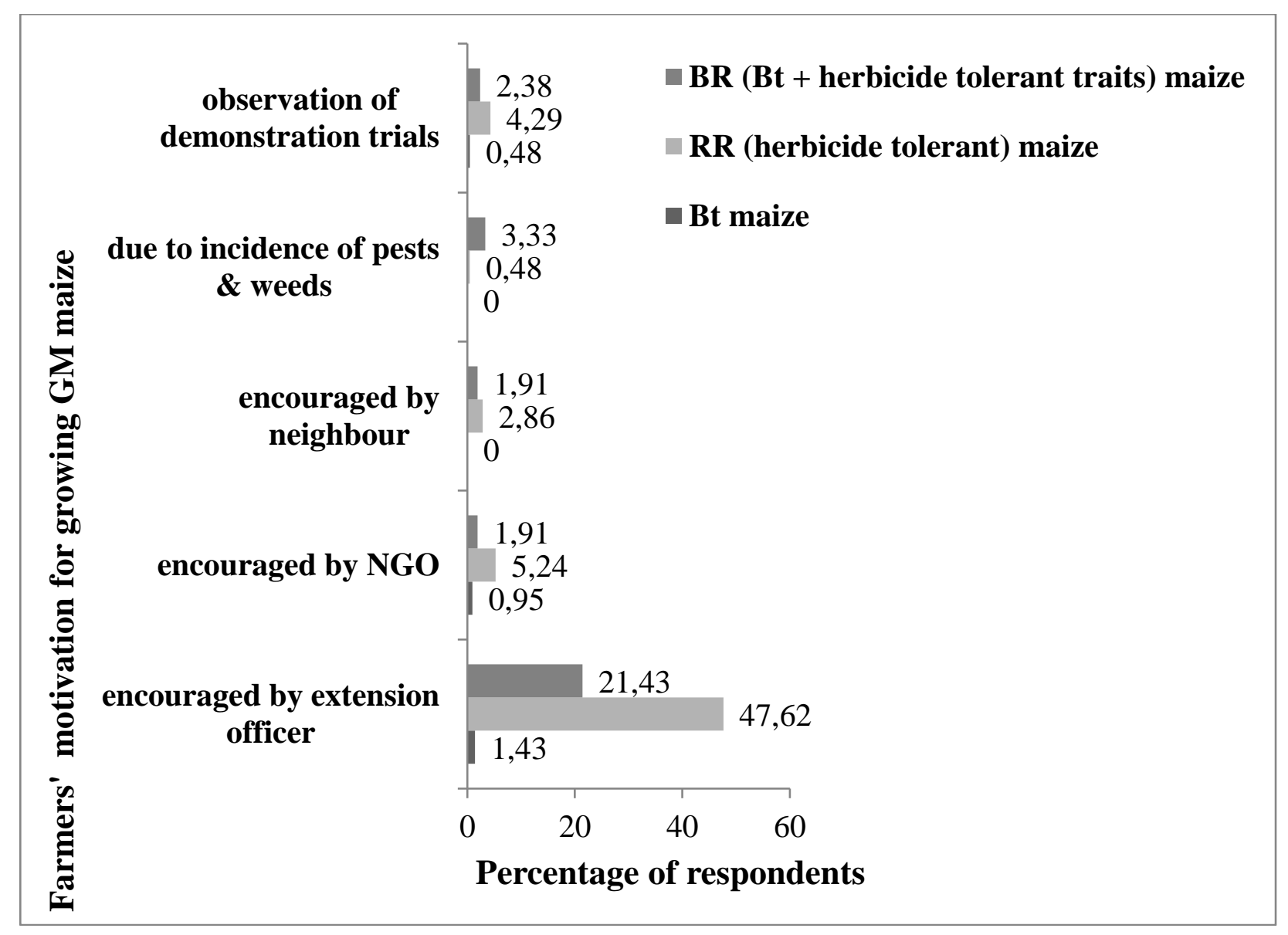

Figure 2: Farmers' primary motivations for deciding to cultivate GM maize.

A very high proportion of farmers $(77.6 \%)$ reported receiving information about GM maize during the last two cropping seasons. The majority $(87.7 \%)$ of these farmers obtained information from extension personnel from DRDAR (Table 1). Most (64\%) farmers however indicated that they were not satisfied with the mode of transfer of GM maize related information to them. About $51 \%$ of interviewed farmers indicated preference for information dissemination through training workshops and seminars whilst $36.3 \%$ indicated preference for information transfer using model farms in their villages (Table 1). Farmers' levels of education had no effect $(P>0.05)$ on where they sourced their information from. 
S. Afr. J. Agric. Ext.,

Vol. 45, No. 2, 2017: 49 - 63

DOI: http://dx.doi.org/10.17159/2413-3221/2017/v45n2a433

Table 1: Farmers' access to information about GM maize

\begin{tabular}{lll}
\hline Source of information & Frequency & Percentage \\
\hline DRDAR & 143 & 87.7 \\
\hline NGO and seed company & 7 & 4.3 \\
\hline GM seed company & 4 & 2.5 \\
\hline Colleague farmer & 3 & 1.8 \\
\hline DRDAR and GM seed company & 3 & 1.8 \\
\hline NGO & 2 & 1.2 \\
\hline DRDAR and NGO & 1 & 0.6 \\
\hline Total & 163 & 100 \\
\hline Preferred mode of information dissemination & Frequency & Percentage \\
\hline Training workshops and seminars & 56 & 50.9 \\
\hline Model farms & 40 & 36.4 \\
\hline Pictorial guides and manuals & 10 & 9.1 \\
\hline Phone call-back service & 2 & 1.8 \\
\hline Workshops and model farms & 2 & 1.8 \\
\hline Total & 110 & 100 \\
\hline Organiser of training & Frequency & Percentage \\
\hline DRDAR & 55 & 85.7 \\
\hline GrainSA & 6 & 9.4 \\
\hline Unknown NGO & 3 & 4.7 \\
\hline Total & 64 & 100 \\
\hline Subjects addressed during training & Frequency & Percentage \\
\hline Mechanisation of farm & 22 & 38.6 \\
\hline Mechanisation, fertilizer application, pest management & 12 & 21.1 \\
\hline Pest management & 11 & 19.3 \\
\hline Cannot recall & 9 & 15.8 \\
\hline Mechanisation and pest management & 1 & 1.8 \\
\hline Row spacing and pest management & 1 & 1.8 \\
\hline Soil sampling, row spacing and seed rate & 1 & 1.8 \\
\hline Total & 57 & 100 \\
\hline & & \\
\hline
\end{tabular}

Rabbinge \& Löffler (2011:264) reported that for farmers to obtain benefits from supposedly good technologies, they must have access to the right information. The majority of farmers in this study had completed not more than seven years of formal education and could be considered as functionally illiterate (Stats SA, 2011). Ozowa (1997:12) suggested that farmers with limited literacy skills may be greatly disadvantaged if information is disseminated using non-participatory approaches for example, print media. Kotey, Assefa, Obi \& Van Den Berg (2016:69) recently reported that only 39.4\% of extension personnel that provided extension and advisory services to smallholder GM maize farmers in the Eastern Cape used participatory methods to disseminate GM maize technology. The use of one-way dissemination media by extension personnel may adversely affect the potential for smallholder farmers to successfully transition to cultivating improved varieties, including GM maize.

\subsection{Farmers' awareness about GM maize technology and compliance with GM crop stewardship requirements}


S. Afr. J. Agric. Ext.,

Vol. 45, No. 2, 2017: 49 - 63

DOI: http://dx.doi.org/10.17159/2413-3221/2017/v45n2a433
Kotey, Assefa \&

Van den Berg.

(Copyright)

About $53 \%$ of interviewed farmers cultivated 'stacked trait' (herbicide + insecticide) BR maize, while $41 \%$ and $0.5 \%$ of farmers cultivated herbicide tolerant and single-gene Bt maize respectively. About 5\% of respondents could not recall the GM maize type they cultivated. Only $43.8 \%$ of farmers interviewed in this study indicated awareness of regulations to follow when planting GM maize. Mostly, the guidelines and regulations farmers were aware of were limited to mono-cropping of GM maize (83\%) and mono-cropping and no sharing of GM maize seeds with friends and neighbours (14.8\%) (Table 2). Approximately, half of interviewed farmers also cultivated OPV maize (47.1\%) and conventional maize hybrids $(8.8 \%)$ obtained from agricultural input shops or recycled from previous harvests in their home gardens. The percentage of farmers who had previously shared GM maize seeds with family members or friends $(6.2 \%)$ or intercropped (5\%) GM maize with other plant species was however very low.

Table 2: Farmers' awareness about GM maize and technology stewardship requirements Awareness of any guidelines or regulations to follow Frequency Percentage when planting GM maize?

\begin{tabular}{lll}
\hline No & 118 & 56.2 \\
\hline Yes & 92 & 43.8 \\
\hline Total & 210 & 100 \\
\hline What are the recommended guidelines /regulations & Frequency & Percentage \\
\hline Mono-cropping & 73 & 83 \\
\hline Mono-cropping and no seed sharing & 13 & 14.8 \\
\hline Use of personal protective equipment & 1 & 1.1 \\
\hline Mandatory use of herbicides and insecticides & 1 & 1.1 \\
\hline Total & 88 & 100 \\
\hline
\end{tabular}

Previous work (Jacobson \& Myhr, 2012:10; Iversen, Grønsberg, Van den Berg, Fischer, Aheto \& Bøhn, 2014:9) in selected villages in the Eastern Cape Province reported that a high proportion of farmers shared GM maize seed with family and colleague farmers. However, very few farmers interviewed in this survey reported sharing seeds with family members or other farmers. A possible explanation for this may be the fact that during previous initiatives that promoted GM maize to smallholder farmers, local villagers were responsible for choosing and ordering seeds and agrochemical inputs (Jacobson \& Myhr, 2012:5). Under the current initiative, procurement of inputs is done at the district level with little participation by farmers (ECRDA, 2013; DRDAR, 2014). Additionally, the supply of inputs to a particular locality is strictly matched to the area of land approved for cultivation. Extension personnel also undertake monitoring during planting to ensure that seeds supplied to farmers are planted in the approved area. It is important to note however that due to logistical and time constraints, this study only reports what pertains in areas within $20 \mathrm{~km}$ from the main access roads in the selected study areas. Typically, communities beyond $20 \mathrm{~km}$ from main access roads are characterised by poor road infrastructure. This can limit the access of farmers in these areas to extension services and information (DAFF, 2012). It is therefore likely that the level of compliance reported here may not hold true for such areas.

When farmers who cultivated Bt/BR maize during the previous two seasons were asked if they had ever been informed about the requirement for the planting of a non-Bt maize refuge area next to their $\mathrm{Bt}$ maize fields, all answered in the negative. As part of GM maize stewardship requirements geared towards delaying the risk of pest resistance evolution in GM maize), farmers planting GM maize are required to plant a refuge area next to their Bt maize 
S. Afr. J. Agric. Ext.,

Vol. 45, No. 2, 2017: 49 - 63

Kotey, Assefa \&

DOI: http://dx.doi.org/10.17159/2413-3221/2017/v45n2a433

Van den Berg.

(Copyright)

fields (Monsanto, 2012). Non-Bt maize fields adjacent to Bt fields have been suggested as an option to structured refuges for Bt maize (Van den Berg \& Campagne, 2014:40). However, it has been observed that unstructured refuges are an inadequate replacement for structured refuges (Siegfried \& Hellmich, 2012:189). The size of maize fields in this study ranged from 0.1 ha to 5.0 ha. Kruger, Van Rensburg \& Van Den Berg (2009:686), previously reported that commercial farmers in South Africa ascribed non-compliance to refuge requirements to the small size of their farming units (25-50 ha). However, with regard to farmers interviewed in this study, lack of awareness of the requirement for the planting of refuges next to Bt maize may be a possible contributory factor.

None of the farmers interviewed in the current study reported signing a technology and stewardship agreement prior to receiving GM seeds for planting. Jacobson \& Myhr (2012:12) also reported that smallholder farmers cultivating GM maize as part of a previous Government initiative in the province did not sign technical agreements. In the commercial maize farming sector, the level of compliance was reportedly increased through the institution of stewardship programmes involving farmer education programmes and the signing of technical agreements between seed companies and farmers, coupled with on-farm inspections (Kruger et al., 2009:687). The signing of technical agreements may therefore contribute to increasing farmers' awareness and compliance to refuge requirements.

The large number of smallholder farmers has previously been suggested a possible constraint to the signing of technical agreements between GM maize seed companies and smallholder farmers (Jacobson \& Myhr, 2012:12). In the current study, the majority of farmers interviewed obtained maize seed through the public extension system. This potentially provides an opportunity for overcoming the challenges posed by the number of smallholder farmers that have to be dealt with. As part of the conditions of the Cropping Programme, farmers within a given locality are required to form a group and elect a committee that assists in the coordination of the programme in the locality. This approach provides the opportunity to sign technical agreements with these committees and subsequently provide training on refuge area planting to committee members who will then undertake farmer to farmer outreach education within their areas. According to Kiptot, Franzel, Hebinck \& Richards (2006:10) farmers who hold leadership positions are effective in spreading information and technologies within their communities. This approach will however require prioritising the training of extension personnel on GM maize technology stewardship requirements as part of the Cropping Programme and collaboration from the GM seed industry and research institutions to develop dissemination approaches that highlights the value of good product stewardship to the long-term sustainability of GM maize.

\subsection{Smallholder farmers' GM maize cultivation practices and perceptions about the technology}

Approximately $79 \%$ of farmers indicated that they experienced insect pest problems before they were introduced to GM maize (Table 3). Important pests cited by farmers included stem borers $(48.4 \%)$ cutworms $(17.9 \%)$, both stem borers and cutworms $(16.8 \%)$, and a complex of stem borers, cutworms and bollworms (9.5\%). According to farmers, they managed these pests on the non-Bt maize farms they previously cultivated using a range of strategies, including insecticide sprays $(74 \%)$, cultural control $(8.3 \%)$ and self-produced insecticidal dusts $(7.3 \%)$. A few (10.4\%) also reported that they did not apply any pest control measures on their farms (Table 3). About 56.8\% of farmers who reported pest incidence on their fields before joining the Cropping Programme cultivated Bt/BR maize during the 2013/14 season. 
S. Afr. J. Agric. Ext.,

Vol. 45, No. 2, 2017: 49 - 63

DOI: http://dx.doi.org/10.17159/2413-3221/2017/v45n2a433

Although a smaller proportion of farmers $(52.5 \%)$ reported pests on their maize fields after introduction to $\mathrm{Bt} / \mathrm{BR}$ maize (Table 4), there was a marked increase in the proportion of farmers $(91 \%)$ that applied insecticides to control pests on their Bt/BR maize fields during the 2013/14 season. Pests reportedly targeted with these sprays included maize stem borers $(60.8 \%)$ or pest complexes that included stem borers $(26.4 \%)$ (Table 4). Field inspections during the 2014/15 season indicated that insecticides obtained at subsidised rates were generally applied during the vegetative ('knee height level') stage of crop development, 5-7 weeks after seedling emergence, using tractor mounted boom sprayers. The application frequency ranged from one spray per season $(90.1 \%)$ to three sprays per season $(0.9 \%)$. Only $9.2 \%$ of Bt/BR maize farmers did not apply insecticides in their fields (Table 4). Participation in GM maize training had no effect $(P>0.05)$ on the number of insecticide sprays made per season. The proportion of farmers that used diversified pest management strategies to control insect pests on their maize fields also decreased following the introduction to Bt/BR maize. Information obtained from farmers during surveys indicated that the adoption of Bt maize generally resulted in a decrease in the use of diversified pest control strategies and an increase in the application of insecticides on maize.

Table 3: Insect pest constraints faced by smallholders prior to cultivating Bt/BR maize.

\begin{tabular}{llc}
\hline Most important pests on non-Bt maize & Frequency & Percentage \\
\hline Stem borers & 46 & 48.4 \\
\hline Cutworms & 17 & 17.9 \\
\hline Stem borers and cutworms & 16 & 16.8 \\
\hline Stem borers, cutworms and bollworms & 9 & 9.5 \\
\hline Unknown pests & 6 & 6.3 \\
\hline Bollworms & 1 & 1.1 \\
\hline Total & 95 & 100 \\
\hline Non-Bt maize growth stage most susceptible & Frequency & Percentage \\
to stem borer infestation & & \\
\hline Seedling & 18 & 16.4 \\
\hline Vegetative & 57 & 51.8 \\
\hline Flowering & 14 & 12.7 \\
\hline Seedling and flowering & 11 & 10 \\
\hline Seedling and vegetative & 9 & 8.2 \\
\hline Vegetative and flowering & 1 & 1 \\
\hline Total & 110 & 100 \\
\hline Pest management strategy & Frequency & Percentage \\
\hline Insecticide sprays & 71 & 74 \\
\hline Unmanaged & 10 & 10.4 \\
\hline Cultural control & 8 & 8.3 \\
\hline Insecticidal dusts & 7 & 7.3 \\
\hline Total & 96 & 100 \\
\hline & &
\end{tabular}


S. Afr. J. Agric. Ext.,

Vol. 45, No. 2, 2017: 49 - 63

Kotey, Assefa \&

DOI: http://dx.doi.org/10.17159/2413-3221/2017/v45n2a433

Van den Berg.

(Copyright)

Table 4: Insect pest management practices adopted by smallholder GM maize farmers.

\begin{tabular}{lll}
\hline $\begin{array}{l}\text { Occurrence of pests on Bt/BR maize } \\
\text { previous season }\end{array}$ & Frequency & Percentage \\
\hline Yes & 64 & 52.5 \\
\hline No & 58 & 47.5 \\
\hline Total & 122 & 100 \\
\hline Insecticide use on Bt/BR previous year & Frequency & Percentage \\
\hline Yes & 101 & 91 \\
\hline No & 10 & 9 \\
\hline Total & 111 & 100 \\
\hline Pests targeted with insecticide & Frequency & Percentage \\
\hline Stem borers & 62 & 60.8 \\
\hline Cutworms and stem borer & 18 & 17.6 \\
\hline Cutworms & 11 & 10.8 \\
\hline Cutworms, stem borers and bollworms & 9 & 8.8 \\
\hline Unknown pests & 2 & 2 \\
\hline Total & 102 & 100 \\
\hline Number of applications & Frequency & Percentage \\
\hline Once per season & 100 & 90.1 \\
\hline Twice per season & 10 & 9.0 \\
\hline Thrice per season & 1 & 0.9 \\
\hline Total & 111 & 100 \\
\hline Source of insecticides & Frequency & Percentage \\
\hline DRDAR & 89 & 87.3 \\
\hline Farmers co-op & 11 & 10.8 \\
\hline Local input shop & 2 & 2 \\
\hline Total & 102 & 100 \\
\hline Crop residue management practice & Frequency & Percentage \\
\hline Left on the field for grazing & 103 & 85.8 \\
\hline Left on field as compost & 16 & 13.3 \\
\hline Burnt & 1 & 1 \\
\hline Total & 120 & 100 \\
\hline & & \\
\hline
\end{tabular}

The primary source $(87.4 \%)$ of insecticides used by farmers was the extension service (DRDAR). These insecticides were supplied at subsidized rates alongside other Cropping Programme inputs. According to Youm, Gilstrap \& Teetes (1990:177) the provision of pesticides at subsidised rates can lead to unnecessary pesticide application on crops. Bt maize has recently been reported as still highly effective against $B$. fusca, the main stem borer pest of maize in the Eastern Cape Province (Kotey, Obi, Assefa, Erasmus \& Van Den Berg 2017:206). Insecticides reportedly applied by farmers may therefore be preventative rather than curative. Kruger et al. (2012:44) reported that a high proportion of maize farmers in the main maize producing region of the Highveld area of South Africa applied insecticides as preventative sprays on Bt maize irrespective of stem borer infestation levels. Hellmich, Albajes, Bergvinson, Prasifka, Wang \& Weiss (2008:145) suggested that reduction of insecticide use alongside the maintenance of other traditional IPM tactics represent the best use of Bt maize. The preventative use of insecticides is also at variance with the basic tenets of IPM which suggests that insecticide use may be appropriate when pest populations cannot 
S. Afr. J. Agric. Ext.,

Vol. 45, No. 2, 2017: 49 - 63

DOI: http://dx.doi.org/10.17159/2413-3221/2017/v45n2a433

be suppressed by other strategies Mannion \& Morse (2013:21) showed that farmers' perceptions of Bt crops can play an important role in the reduction (or not) in the volume of pesticides applied onto such crops. In this study, there was a significant $(P=0.004)$ relationship between type of GM maize currently cultivated and farmers' perception of the benefit of cultivating GM maize. More farmers cultivating hybrids with both Bt and herbicide tolerant traits (BR) maize perceived it as drought tolerant whilst more farmers planting hybrids with only the herbicide tolerance trait (RR) perceived it as early maturing. The majority of farmers that cultivated BR maize (62.8\%) and RR maize (61.8\%) however cited higher yields as the main benefit obtained from cultivating GM maize (Figure 3). The proportion of respondents that were aware of GM maize as an insect pest and weed management tool was generally low. Only $10.7 \%$ of BR maize farmers and $(8.1 \%)$ of RR maize farmers respectively realized that stem borer resistance or herbicide tolerance (low labour input) were the advantages associated with GM maize cultivation. Furthermore, only $4.9 \%$ of BR maize farmers and 34\% of RR maize farmers who reported high yield as an advantage of GM maize related this advantage to the stem borer resistance and herbicide tolerance traits of the GM maize varieties they cultivated.

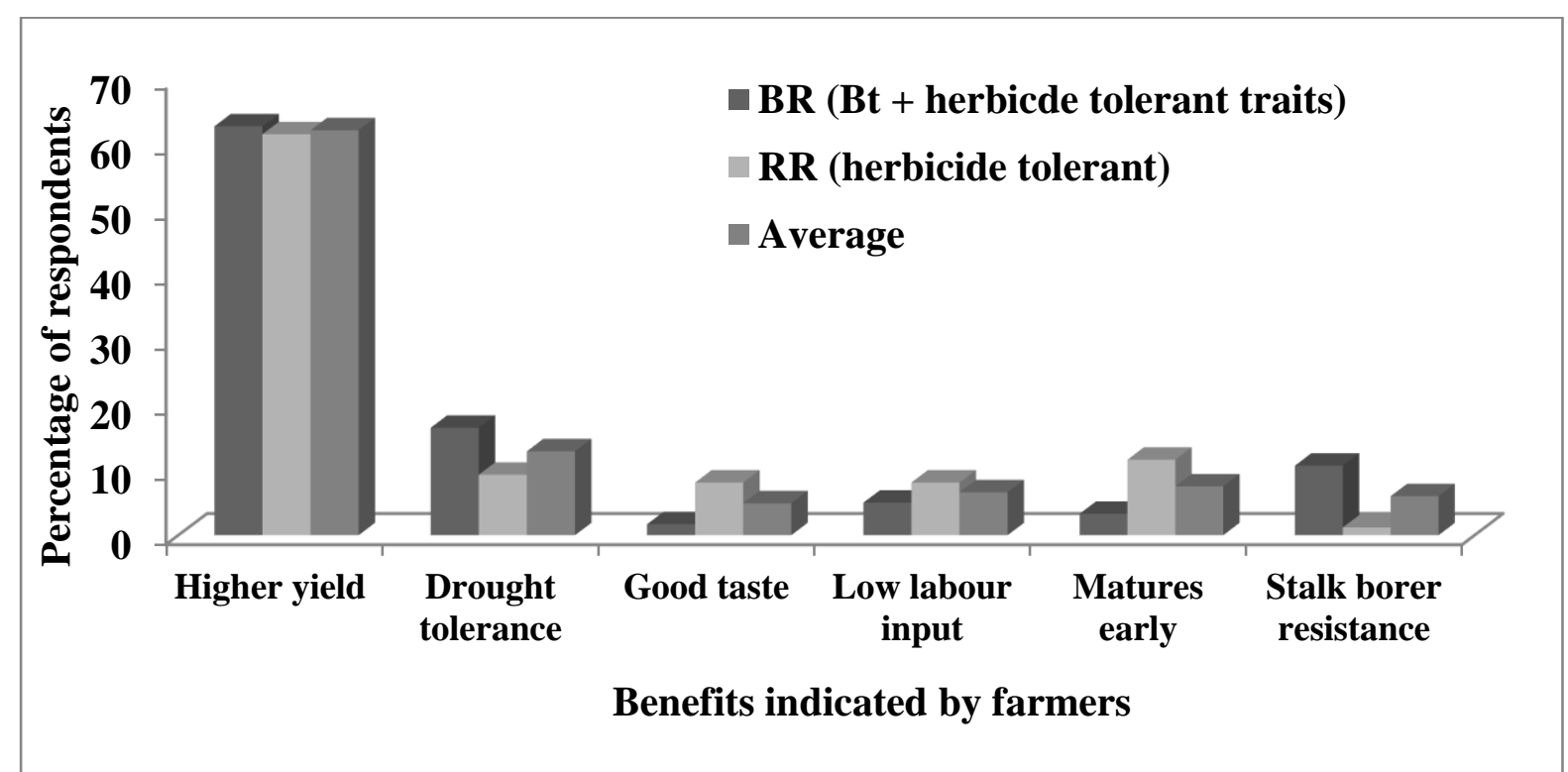

Figure 3: Farmers' perceptions of the benefits of GM maize cultivation.

Many farmers (38.4\%) reported the weed presence in their GM maize (BR and RR) fields to be comparatively lower than on their conventional maize fields (Table 5). Approximately $71.4 \%$ of respondents relied solely on herbicides to control weeds whilst $24.8 \%$ of respondents supplemented herbicide sprays with mechanical weed control. Forty seven percent of farmers perceived herbicides to exert a good level of control against weeds whilst $28.4 \%$ had the perception that the herbicides they sprayed provided weak control (Table 5). The weed management strategy adopted by farmers was significantly $(P<0.001)$ related to farm size. Farmers with smaller farm sizes were more likely to use hoe-weeding as a sole control tactic or use it to supplement herbicide application. 
S. Afr. J. Agric. Ext.,

Vol. 45, No. 2, 2017: 49 - 63

Kotey, Assefa \&

DOI: http://dx.doi.org/10.17159/2413-3221/2017/v45n2a433

Van den Berg.

(Copyright)

Table 5. Weed management practices used in GM maize fields of smallholder farmers.

\begin{tabular}{lll}
\hline Incidence of weeds on farm & Frequency & Percentage \\
\hline Yes & 151 & 71.9 \\
\hline No & 58 & 27.6 \\
\hline Don't know & 1 & 0.5 \\
\hline Total & 210 & 100 \\
\hline Assessment of weed incidence & Frequency & Percentage \\
\hline Few weeds & 58 & 38.4 \\
\hline Normal & 52 & 34.4 \\
\hline Many weeds & 41 & 27.2 \\
\hline Total & 151 & 100 \\
\hline Management strategy & Frequency & Percentage \\
\hline Herbicide sprays & 150 & 71.4 \\
\hline Hoe-weeding and herbicide sprays & 52 & 24.8 \\
\hline Hoe-weeding & 8 & 3.8 \\
\hline Total & 210 & 100 \\
\hline Evaluation of the level of control & Frequency & Percentage \\
\hline Good & 96 & 47.8 \\
\hline Poor & 57 & 28.4 \\
\hline Very good & 42 & 20.9 \\
\hline Don't know & 6 & 3.0 \\
\hline Total & 210 & 100 \\
\hline
\end{tabular}

The Eastern Cape Province has a high rate of rural-urban migration and high prevalence of HIV/AIDS (DEDEAT, 2013; Stats SA, 2015). Most farmers are also of an advanced age (Assefa \& Van den Berg, 2009:220). Smallholder farming systems in the province are therefore labour constrained (Assefa \& Van den Berg, 2009:221). The labour-saving advantage of herbicide tolerant maize is therefore very important for smallholder farmers in the province (Regier, Dalton \& Williams, 2012:331). The use of glyphosate as a sole method of weed control is however not sustainable since it can exert a high selective pressure for the evolution of weed populations dominated by resistant individuals (Brookes \& Barfoot, 2016:86). Lack of awareness of the ability of weeds to evolve resistance to herbicides may be a major hindrance to the adoption of diversified weed management tactics (Johnson, Owen, Kruger, Young, Shaw, Wilcut, Jordan \& Weller 2009:311) by farmers.

\section{CONCLUSIONS}

The results reported in this study indicated that the introduction of smallholder farmers to insect and herbicide tolerant GM maize resulted in increased use of externally sourced inputs. The study also highlighted gaps in the implementation of regulations critical to sustaining the long-term efficacy of GM maize technology against target pests and weeds. Historically, extension and advisory services have played a critical role in facilitating the adoption of improved agricultural practices. To this end, the use of participatory GM maize dissemination approaches and timely delivery of reliable information about specific constraints targeted by GM maize and the measures required to preserve its long-term efficacy can facilitate beneficial and sustainable cultivation of GM maize. 
S. Afr. J. Agric. Ext.,

Vol. 45, No. 2, 2017: 49 - 63

DOI: http://dx.doi.org/10.17159/2413-3221/2017/v45n2a433

REFERENCES
Kotey, Assefa \&

Van den Berg.

(Copyright)

ABADI GHADIM, A.K. \& PANNELL, D.J. 1999. A conceptual framework of adoption of an agricultural innovation. J. Agri. Econ., 21:145-154.

ADESINA, A.A., LANGYINTUO, A., BUGO, N., MAKINDE, K., BIGIRWA, G. \& WAKIUMU, J. 2011. Improving farmers' access to agricultural inputs and finance: approaches and lessons from Sub-Saharan Africa. Proceedings of the Conference on New Directions for Smallholder Agriculture 24-25 January, 2011, Rome, Italy.

ASSEFA, Y. \& VAN DEN BERG, J. 2009. Genetically modified maize: adoption practices of small-scale farmers in South Africa and implications for resource poor farmers on the continent. Asp. Appl. Biol., 96:215-223.

BROOKES, G \& BARFOOT, P. 2016. Environmental impacts of genetically modified (GM) crop use 1996-2014: Impacts on pesticide use and carbon emissions. GM Crops Food 7(2):84-116.

CAMERON, P.J. 2007. Factors influencing the development of integrated pest management (IPM) in selected vegetable crops: a review. New Zeal. J. Crop Hort., 35:365-384.

CIMMYT (INTERNATIONAL MAIZE AND WHEAT IMPROVEMENT CENTER). 1993. The adoption of agricultural technology: A guide for survey design. CIMMYT Economics program, El Batán, Mexico.

COMMISSION FOR GENDER EQUALITY. 2009. A gendered analysis of land reform policy and implementation outcome in South Africa (2006-2008/09). Commission for Gender Equality. Republic of South Africa.

DAFF, 2012. A framework for the development of smallholder farmers through cooperative development. Directorate: Co-operative and Enterprise Development, Department of Agriculture Forestry and Fisheries. 8pp.

DEDEAT (DEPARTMENT OF ECONOMIC DEVELOPMENT, ENVIRONMENTAL AFFAIRS AND TOURISM). 2013. The Eastern Cape socio-economic review and outlook; An independent analysis of the Eastern Cape economy. University of Pretoria. DEDEAT, 5605, Bhisho, South Africa.

DRDAR. 2014. Annual Report Vote 8 financial year 2013/14, Vote 8: Department of Rural Development and Agrarian Reform, Province of the Eastern Cape.

DOSS, C.R. \& MORRIS, M.L. 2001. How does gender affect the adoption of agricultural innovations? The case of improved maize technology in Ghana. Agri. Econ., 25:2739.

ECRDA (EASTERN CAPE RURAL DEVELOPMENT AGENCY). 2013. Annual report 2012/2013. ECRDA, 28 Alexandra Road, King Williams Town, 5600. South Africa.

FAO (FOOD AND AGRICULTURE ORGANISATION), 2011. The state of food and agriculture-women in agriculture closing the gender gap for development. Food and Agriculture Organisation of the United Nations, Rome, Italy.

FISCHER, K., VAN DEN BERG, J. \& MUTENGWA, C. 2015. Is Bt maize effective in improving South African smallholder agriculture? S. Afri. J. Sci., 111:1-2.

GOUSE, M. 2012. GM maize as subsistence crop: The South African smallholder experience AgBioForum 15:163-174.

GREEN, J.M. \& OWEN, M.D.K. 2010. Herbicide-resistant crops: Utilities and limitations for herbicide-resistant weed management. J. Agric. Food Chem., 59:5819-5829.

HART, T. \& ALIBER, M., 2012. Inequalities in agricultural support for women in South Africa. Human Sciences Research Council policy brief, November, 2012. Available at www.hsrc.ac.za/uploads/pageContent/3025/InequalitiesLR.pdf

HELlMICH, R.L., ALBAJES, R., BERGVINSON, D., PRASIFKA, J.R., WANG, Z.Y. \& WEISS, M.J. 2008. The present and future role of insect-resistant genetically 

Integration of Insect-resistant Genetically Modified Crops Within IPM Programs. Springer Science + Business Media. Dordrecht, The Netherlands. Pp 119-158.

IVERSEN, M., GRØNSBERG, I.M., VAN DEN BERG, J., FISCHER, K., AHETO, D.W. \& BØHN, T. 2014. Detection of transgenes in local maize varieties of small-scale farmers in Eastern Cape, South Africa. PLoS One 9: e116147.

JACOBSON, K. 2013. From betterment to Bt maize: Agricultural development and the introduction of genetically modified maize to South African smallholders. Doctoral Thesis, Department of Urban and Rural Development. Swedish University of Agricultural Sciences, Uppsala, Sweden. Acta Universitatis Agriculturae Sueciae 2013:28.

JACOBSON, K. \& MYHR, A.I. 2012. GM crops and smallholders: biosafety and local practice. J. Environ. Dev., 22:104-124.

JOHNSON, W.G., OWEN, M.D.K. KRUGER, G.R., YOUNG, B.G., SHAW, D.R., WILCUT, J.W., JORDAN, D.L. \& WELLER, S.C. 2009. U.S. farmer awareness of glyphosate-resistant weeds and resistance management strategies. Weed Tech., 23: $08-312$.

KIPTOT, E., FRANZEL, S., HEBINCK, P. \& RICHARDS, P. 2006. Sharing seed and knowledge: farmer to farmer dissemination of agroforestry technologies in western Kenya. Agroforest. Syst. 68:167-179.

KOTEY, D.A., OBI, A., ASSEFA, Y., ERASMUS, A. \& VAN DEN BERG, J. 2017. Monitoring resistance to Bt maize in field populations of Busseola fusca (Fuller) (Lepidoptera: Noctuidae) from smallholder farms in the Eastern Cape Province of South Africa. Afr. Entomol., 25(1):200-209.

KOTEY, D.A, ASSEFA, Y., OBI, A. \& VAN DEN BERG, J. 2016. Disseminating genetically modified (GM) maize technology to smallholder farmers: perceptions, practices and awareness of extension personnel in the Eastern Cape Province of South Africa. SASAE 44(1):59-74.

KRUGER, M., VAN RENSBURG, J.B.J. \& VAN DEN BERG, J. 2009. Perspective on the development of stem borer resistance to Bt maize and refuge compliance at the Vaalharts irrigation scheme in South Africa. Crop Protection 28:684-689.

KRUGER, M., VAN RENSBURG, J.B.J. \& VAN DEN BERG, J. 2012. Transgenic Bt maize: farmers' perceptions, refuge compliance and reports of stem borer resistance in South Africa. J. Appl. Entomol. 136:38-50.

MANNION, A.M. \& MORSE, S. 2013. GM Crops 1996-2012: A review of agronomic, environmental and socio-economic impacts, University of Surrey, Centre for Environmental Strategy (CES), working paper 04/13, Centre for Environmental Strategy, University of Surrey, UK, Guildford, Surrey GU2 7XH, United Kingdom. Retrieved from www.surrey.ac.uk/ces/activity/publications/index.htm

MONSANTO. 2012. User guide for the production of yieldgard, Roundup Ready corn 2 and yieldgard with Roundup Ready corn 2. Monsanto, Bryanston, 2021 South Africa.

OZOWA, V.N. 1997. Information needs of small scale farmers in Africa: The Nigeria example. CGIAR News 4 (3): 10-12. Consultative Group for International Agricultural Research (CGIAR) Secretariat, Washington, D.C., United States of America.

PANNAR. 2014. Product catalogue, Pannar Ltd. Greytown, 3250, KwaZulu-Natal, South Africa.

RABBINGE, R. \& LÖFFLER, H. 2011. Small scale farming as a business: Creating an enabling business environment and improving small farm technology and sustainable resource management. In: Proceedings of the Conference on New Directions for 
S. Afr. J. Agric. Ext.,

Vol. 45, No. 2, 2017: 49 - 63

DOI: http://dx.doi.org/10.17159/2413-3221/2017/v45n2a433
Kotey, Assefa \&

Van den Berg.

(Copyright)

Smallholder Agriculture, 24-25 January 2011, Rome, Italy. International Fund for Agricultural Development (IFAD), Via Paolo Di Dono, Rome, Italy. Pp 261-265.

REGIER, G.K., DALTON, T.J. \& WILLIAMS, J.R.,2012. Impact of genetically modified maize on smallholder risk in South Africa. AgBioForum 15(3):328-336.

SIEGFRIED, B.D. \& HELLMICH, R.L. 2012. Understanding successful resistance management. GM Crops Food 3:184-193.

STATS SA. 2011. General household survey 2009. Statistical release P0318, Statistics South Africa, Pretoria, 0001, South Africa.

STATS SA. 2015. Mid-year population estimates 2014. Statistical release P0302, Statistics South Africa, Pretoria, 0001 South Africa.

STONE, G.D., 2011. Field versus farm in Warangal: Bt cotton, higher yields, and larger questions. World Development, 39(3):387-398.

SWANSON, B.E., \& RAJALAHTI, R. 2010. Strengthening Agricultural Extension and Advisory Systems: Procedures for Assessing, Transforming, and Evaluating Extension Systems. Washington: Agriculture and Rural Development Discussion Paper 45.

TABASHNIK, B.E. 1994. Evolution of resistance to Bacillus thuringiensis. Annu. Rev. Entomol., 39:47-79.

YOUM, O., GILSTRAP, F.E. \& TEETES, G.L. 1990. Pesticides in traditional farming systems in West Africa. J. Agri. Entomol., 7: 171-181.

VAN DEN BERG, J. \& CAMPAGNE, P. 2014. Resistance of Busseola fusca to Cry1Ab Bt maize plants in South Africa and challenges to insect resistance management in Africa. In: Soberón, M. Gao, Y. \& Bravo, A. (Eds), Characterization and Strategies for GM Crops Producing Bacillus thuringiensis Toxins. CABI Biotechnology Series, CABI International, Wallingford, UK, 4: 36-48.

VAN DEN BERG, J., HILLBECK, A. \& BØHN, T. 2013. Pest resistance to Cry1 Ab Bt maize: field resistance, contributing factors and lessons from South Africa. Crop Prot., 54:154-160. 